\title{
Nitrogen and Organics Removal during Riverbank Filtration along a Reclaimed Water Restored River in Beijing, China
}

\author{
Weiyan Pan ${ }^{1,2}$, Quanzhong Huang $1,3, * \mathbb{1}$ and Guanhua Huang 1,3 \\ 1 Chinese-Israeli International Center for Research and Training in Agriculture China Agricultural University, \\ Beijing 100083, China; weiyanpan@126.com (W.P.); ghuang@cau.edu.cn (G.H.) \\ 2 School of Water conservancy and Environment, University of Jinan, Jinan 250022, China \\ 3 Center for Agricultural Water Research, China Agricultural University, Beijing 100083, China \\ * Correspondence: huangqzh@cau.edu.cn; Tel.: +86-10-6-273-7148
}

Received: 30 November 2017; Accepted: 5 April 2018; Published: 17 April 2018

\begin{abstract}
Reclaimed water has been widely used to restore rivers and lakes in water scarce areas as well as in Beijing municipality, China. However, refilling the rivers with reclaimed water may result in groundwater pollution. A three-year field monitoring program was conducted to assess the effect of a riverbank filtration (RBF) system on the removal of nitrogen and organics from the Qingyang River of Beijing, which is replenished with reclaimed water. Water samples from the river, sediment, and ground water were collected for $\mathrm{NO}_{3}-\mathrm{N}, \mathrm{NH}_{4}-\mathrm{N}$, and chemical oxygen demand (COD) was measured. The results indicate that about $85 \%$ of $\mathrm{NO}_{3}-\mathrm{N}$ was removed from the riverbed sediments. Approximate $92 \%$ of $\mathrm{NH}_{4}-\mathrm{N}$ was removed during the infiltration of water from river to aquifer. On average, $54 \%$ of COD was removed by RBF. The attenuation of $\mathrm{NO}_{3}-\mathrm{N}$ through RBF to the groundwater varied among seasons and was strongly related to water temperature. On the other hand, no obvious temporal variability was identified in the removal of COD. These results suggest that the RBF system is an effective barrier against $\mathrm{NO}_{3}-\mathrm{N}, \mathrm{NH}_{4}-\mathrm{N}$ and COD in the Qingyang River, as well as those rivers with similar geological and climatic conditions refilled with reclaimed water.
\end{abstract}

Keywords: chemical oxygen demand; groundwater; nitrogen; riverbank filtration

\section{Introduction}

Beijing faces severe problems including water scarcity and water pollution, which together are becoming key factors restricting development [1]. With the increase in scale of wastewater collection, treatment and disposal, treated wastewater has been widely reused in agricultural irrigation, landscape water and domestic supplies [2,3]. The majority of rivers have desiccated due to prolonged drought and excessive consumption. Thus, reclaimed water (i.e., treated municipal wastewater) has become a vital and inevitable water source for the urban landscape and rivers in Beijing. According to the Beijing Water Authority, more than $8 \times 10^{8} \mathrm{~m}^{3}$ of reclaimed water was utilized in 2014, accounting for $23 \%$ of total water consumption. Nearly $5 \times 10^{8} \mathrm{~m}^{3}$ of reclaimed water was used to replenish rivers and lakes [4]. According to the Surface Water Quality Standard, reclaimed water in Beijing typically meets the standard of level V2 for surface water quality, which is characterized by higher concentrations of nitrate, ammonium, salt and organic matter than those in freshwater $[5,6]$. Consequently, the replenishment of rivers and lakes with reclaimed water may result in groundwater contamination, which may pose a potential risk to human health. The presence and fate of organic carbon and nitrogen during bank filtration have received increased attention. Moreover, the occurrence of nitrogen and organic pollution in groundwater has been found to be a problem in Beijing and 
surrounding areas in recent years. However, the environmental effects of long-term exposure to nitrate and organic compounds, especially organic micropollutants, are largely ignored. Specifically, uncertainty remains in our knowledge of the magnitude and spatial-temporal changes of nitrogen and chemical oxygen demand (COD) in groundwater in our study area.

Riverbank filtration (RBF) is a natural aquifer recharge process. It has been widely used to recover filtrated water from RBF for domestic use in recent years. As surface water flows from the river through the stream-bed and aquifer to the pumping wells, a wide variety of contaminants are naturally attenuated [7-12]. Nevertheless, the differences in hydrogeological conditions, climatic conditions and river water quality in any specific area may cause different results even with the same riverbank filtration system. Both the hydrogeological conditions and saturated/unsaturated conditions comprising the infiltration zone are important in the removal of river-borne pollutants [13]. Various biogeochemical activities take place within riverbed sediments [14]. Previous studies have found that redox conditions in sediment play an important role in altering the chemistry of infiltrating water [15]. Others have found a positive effect of available organic carbon on the denitrification rates in river sediments [16-18].

The processes of RBF that improve water quality are influenced by several factors such as temperature, redox conditions, the characteristics of the saturated zone, river water quality [19-21] and different hydrogeological conditions [22,23]. For example, seasonal changes in river flow and temperature can result in rapid changes between aerobic and anoxic conditions. The variable microbial activities under different redox conditions can affect the attenuation efficiency of water quality parameters during RBF [24]. Higher temperatures generally increase the mineralization potential $[25,26]$. Some researchers $[19,27]$ have found that long flow paths and travel times between river water and pumping wells have a beneficial effect on the elimination of nitrate and organic compounds, but the presence of anoxic groundwater conditions can have undesirable effects, such as the dissolution of manganese and iron oxides and ammonification.

Reclaimed water has increasingly been used in rivers and lakes in Beijing in recent years, while the environmental risks to groundwater still remain poorly known $[28,29]$. The mechanism for contaminant removal and the corresponding impact factors through the RBF system with reclaimed water need to be further investigated. Therefore, a RBF system was selected, and the removal processes of $\mathrm{NO}_{3}-\mathrm{N}$, $\mathrm{NH}_{4}-\mathrm{N}$, and COD through riverbank filtration over a three-year period (2013-2015) were analyzed. The aims of the present work are to: (i) investigate the attenuation behavior of $\mathrm{NO}_{3}-\mathrm{N}, \mathrm{NH}_{4}-\mathrm{N}$, and COD along the infiltration path from the river to groundwater; and (ii) examine the influence of seasonal variations of environmental factors on the removal of $\mathrm{NO}_{3}-\mathrm{N}, \mathrm{NH}_{4}-\mathrm{N}$, and COD.

\section{Materials and Methods}

\subsection{Site Description}

The Qingyang River, which forms the principal source for the dragon-shaped water system in the Beijing Olympic Forest Park, is located at $40^{\circ} 00^{\prime}-40^{\circ} 02^{\prime} \mathrm{N}$ and $116^{\circ} 22^{\prime}-116^{\circ} 24^{\prime} \mathrm{E}$ at the northern end of the Beijing city axis. Qingyang River is an artificial river without natural flow, and it is refilled with reclaimed water. With a total area of $0.25 \mathrm{~km}^{2}$, the $9 \mathrm{~km}$-long Qingyang River comprises the Qinghe diversion canal and the Yangshan drainage ditch, with the latter discharging excess water into the Qinghe River (Figure 1). The Qingyang River has been recharged by reclaimed water since 2008, with approximately $1.5 \times 10^{6} \mathrm{~m}^{3}$ of reclaimed water discharged into the surface system between March and November each year. The daily discharge was around $6048 \mathrm{~m}^{3} / \mathrm{d}$ during the period of reclaimed water recharge (from 15 March to 17 November in 2014). The reclaimed water was replenished into the Qingyang River via the conveyance pipeline in the northwest part of the Qinghe diversion canal, and the recharge point was $1.1 \mathrm{~km}$ from the sampling section (Figure 1). The recharge rate of reclaimed water was around $0.07 \mathrm{~m}^{3} \mathrm{~s}^{-1}$. 
The results of precipitation, river stage and groundwater levels are shown in Figure 2. As shown in Figure 2, the annual rainfall was $457 \mathrm{~mm}$ and the largest precipitation event (106 $\mathrm{mm}$ ) was recorded on 2 September in 2014. In the early recharge period, a sudden surge in the river stage prompted an emergency release of the excess storm water from the drainage system to Qinghe River. The river stage showed subtle variation over the course of the year, with an obvious decrease occurring between August and September owing to flood discharge. The average width of the watercourse is $18.0 \pm 5.0 \mathrm{~m}$. As shown in Figure 2, the groundwater table is about 4.0-5.0 m below the ground surface, and was primarily influenced by river flow during the study period. At the study site, continuous infiltration of the Qingyang River through a saturated zone can be confirmed. The elevation of the river surface (around $36.4 \mathrm{~m}$ ) is higher than the groundwater level $(33.0 \mathrm{~m})$, and the river channel was continuously recharged with reclaimed water for a long period, therefore, the river recharges the groundwater along the flow direction, as shown in Figure 3.
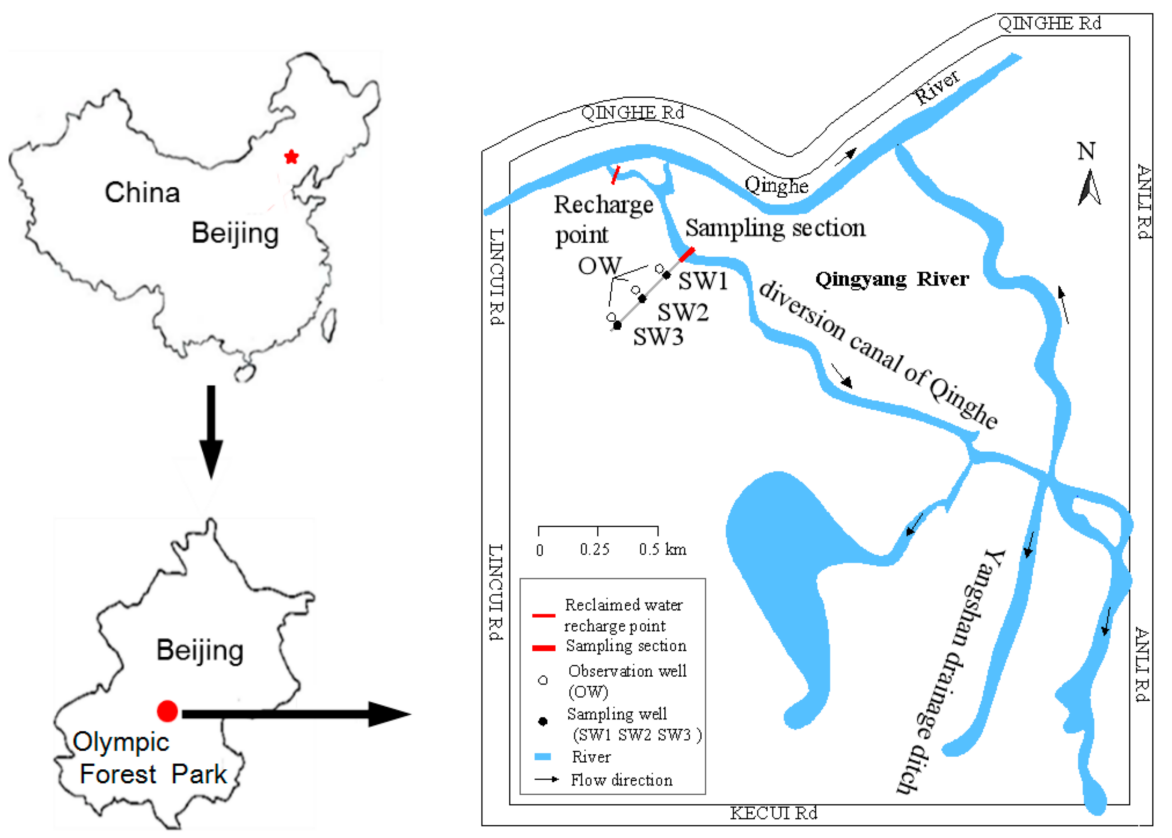

Figure 1. Location of the study site and location of sampling points.

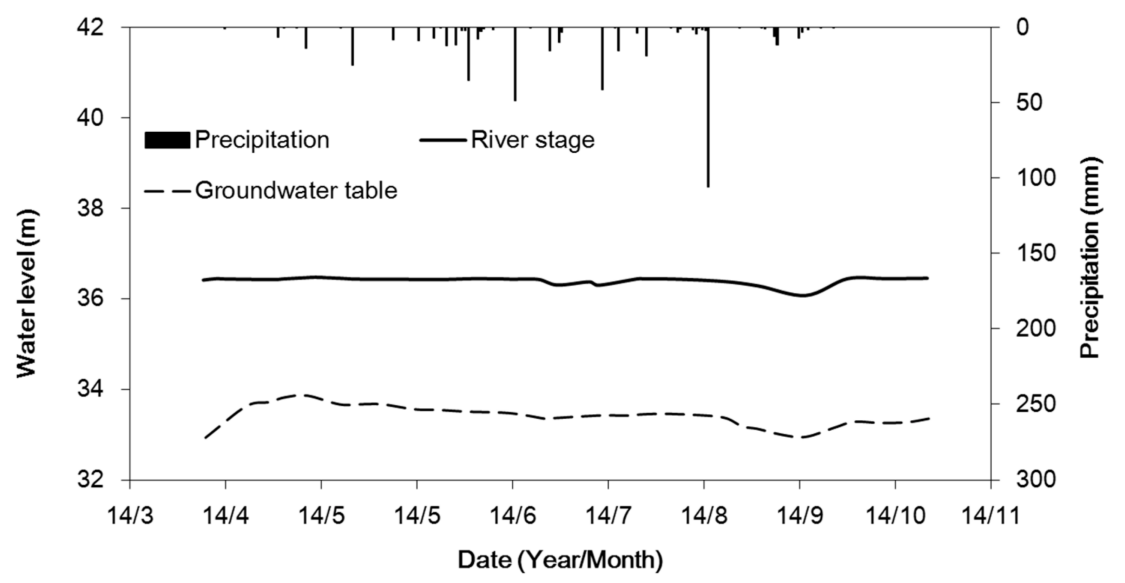

Figure 2. Variation of the river stage and groundwater table in sampling well 3 and precipitation from March to November in 2014. 


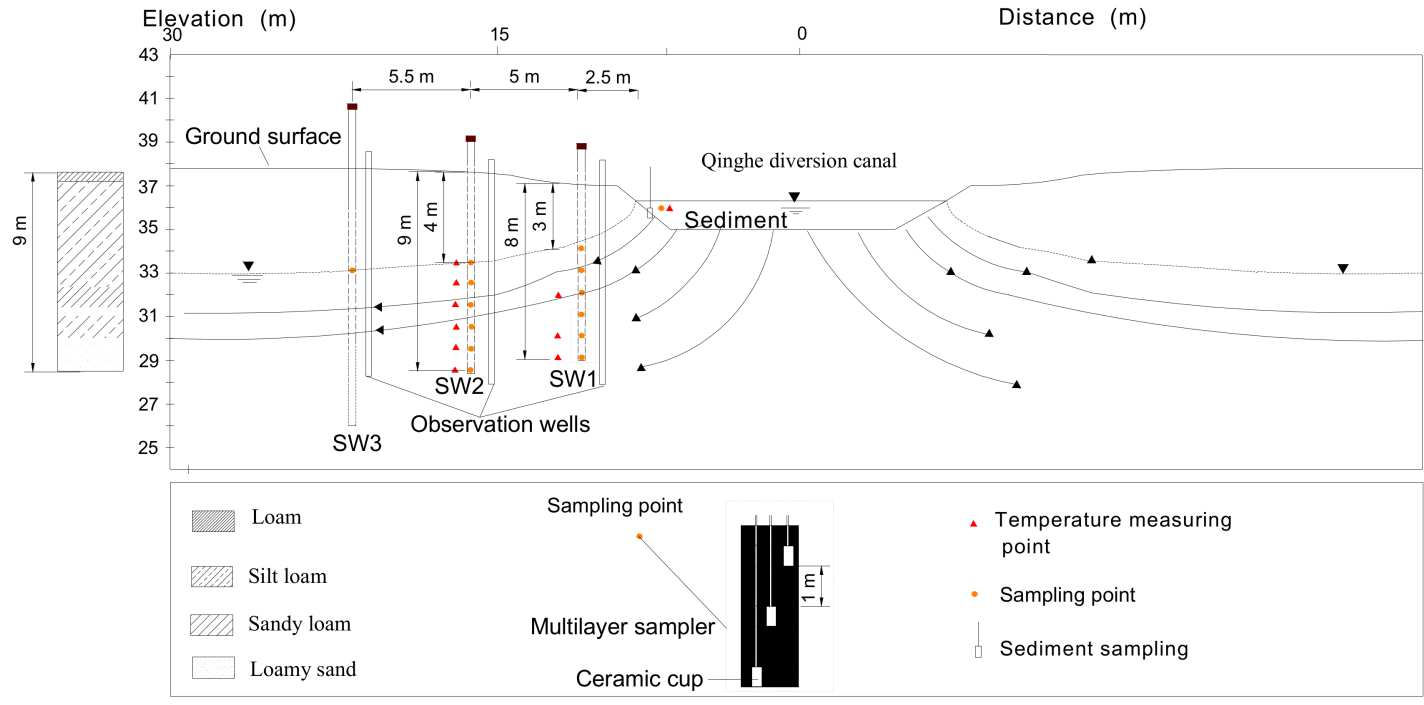

Figure 3. Schematic of the sampling points at the sampling section.

Olympic Forest Park is characterized by a natural landscape with vegetation of weeds such as Chenopodium album, Eleusine indica and Artemisia annua, well-maintained grass of clipped Zoysia japonica and artificial forestland such as Platycladus orientalis and Picea asperata. Soil samples were collected at this monitoring site at $0.2 \mathrm{~m}$ intervals, from the surface to a depth of $9 \mathrm{~m}$. Soil particle size distribution was analyzed using a Mastersize 2000 (Malvern Instruments, Malvern, UK) and organic matter content was measured using the potassium dichromate method. Particle size distribution and organic matter content are provided in Table 1 . The hydraulic conductivity ( $K$-value, $\mathrm{m} /$ day) of the soil at the monitoring site was estimated by the Rosetta model developed by the United States Salinity Laboratory [30]. The soil profile exhibited a sandwich-like texture distribution. Layered heterogeneity exists in the unsaturated and saturated zones of the study area. This may cause preferential flow, however, it is difficult for us to exactly identify the pathway of preferential flow. Additionally, the biogeochemical processes in different layers of the aquifer may be different due to the difference in clay content.

Table 1. Particle size distribution and organic matter content in the soil profile at the monitoring site.

\begin{tabular}{|c|c|c|c|c|c|c|c|}
\hline \multirow{2}{*}{ Soil Depth (cm) } & \multirow{2}{*}{$\begin{array}{c}\text { Sampling } \\
\text { Numbers (n) }\end{array}$} & \multicolumn{3}{|c|}{ Particle Size Distribution (\%) } & \multirow{2}{*}{$\begin{array}{c}\text { Organic Matter } \\
\text { Content }(\%)\end{array}$} & \multirow{2}{*}{ Soil Texture } & \multirow{2}{*}{$K$-Value (m/day) } \\
\hline & & $0.01-2 \mu \mathrm{m}$ & $2-50 \mu \mathrm{m}$ & 50-2000 $\mu \mathrm{m}$ & & & \\
\hline $0-40$ & 6 & 9 & 47 & 44 & 3.26 & Loam & 0.31 \\
\hline $40-100$ & 9 & 12 & 52 & 36 & 2.51 & Silt loam & 0.31 \\
\hline $100-160$ & 9 & 12 & 56 & 32 & 1.24 & Silt loam & 0.32 \\
\hline $160-240$ & 12 & 16 & 65 & 19 & 1.37 & Silt loam & 0.20 \\
\hline $240-320$ & 12 & 12 & 53 & 35 & 0.42 & Silt loam & 0.31 \\
\hline $320-360$ & 6 & 10 & 59 & 31 & 0.58 & Silt loam & 0.40 \\
\hline $360-520$ & 24 & 15 & 68 & 17 & 2.88 & Silt loam & 0.21 \\
\hline $520-610$ & 15 & 5 & 27 & 68 & 0.55 & Sandy loam & 0.61 \\
\hline $610-650$ & 12 & 4 & 22 & 74 & 0.53 & Loamy sand & 0.75 \\
\hline $650-750$ & 15 & 10 & 50 & 40 & 1.78 & Silt loam & 0.33 \\
\hline $750-900$ & 24 & 5 & 18 & 77 & 0.2 & Loamy sand & 0.80 \\
\hline
\end{tabular}

\subsection{Water Sample Collection}

Samples of reclaimed water, river water, interstitial water and groundwater were collected during the study period. Reclaimed water samples were directly collected from the conveyance pipeline, and were collected once a month from March to December in 2014. One sampling section was selected to investigate the water quality of the Qingyang River (Figure 1). River water samples were collected about $50 \mathrm{~cm}$ below the water surface in the sampling section. Additionally, sediment samples were collected for interstitial water using a sampling tube (made of cylindrical polyethylene, with a length 
of $100 \mathrm{~cm}$, and the diameter of $4 \mathrm{~cm}$ ). The sampling points were chosen in the top $30 \mathrm{~cm}$ layer of the riverbed sediment in the riverbed close to the sampling section. The interstitial water was collected in the summer months (from July to September) and the winter months (from November to December) in 2014. A total of 15 sediment samples for interstitial water were taken in the riverbed during the sampling period. The mixture of samples at different locations was used as the final sediment samples for the same sampling time. Prior to analysis, water in the sediment was isolated in a laboratory via centrifuging and filtering for $\mathrm{NO}_{3}-\mathrm{N}$ and COD. Water samples in the sediment for $\mathrm{NH}_{4}-\mathrm{N}$ analysis were obtained just by the vibration and filtering process.

Three groundwater sampling wells were prepared at the sampling section (see Figure 3). Sampling wells 1 (SW1), 2 (SW2), and 3 (SW3) were located approximately 2.5, 7.5, and $13 \mathrm{~m}$ from the riverbank, respectively (Figure 3). Each of the wells had a diameter of $0.2 \mathrm{~m}$ and screened along their full length, and was installed with multilayer samplers, which were used to collect groundwater samples. The multilayer samplers consisted of ceramic cups connected to sample bottles via Polyvinyl chloride tubing with a diameter of $5 \mathrm{~cm}$. The porous ceramic cups were buried at different depths in the sampling wells. Firstly, negative pressure inside the sampling bottle was created by a vacuum pump. Then, the negative pressure inside the sampling bottle caused water flow from the soil to a sampling bottle. Clusters of ceramic cups were set at the depths of 3, 4, 5, 6, 7, and $8 \mathrm{~m}$ in SW1 and 4, 5, 6, 7, 8, and $9 \mathrm{~m}$ in SW2 (see Figure 3). The diameter of SW3 was $20 \mathrm{~cm}$ and water samples were collected from the groundwater surface directly via a sampling bottle. River and groundwater samples were collected two to three times a month from September to December in 2013, and from March to December in 2014 and 2015, respectively.

The temperatures of the river water, interstitial water and groundwater was measured by a thermocouple sensor. The thermocouple sensors were installed at different depths in the sampling wells (SW1 and SW2). The groundwater temperature in SW1 (at the depths of 5, 7 and $8 \mathrm{~m}$ ) and SW2 (at the depths of 4, 5, 6, 7, 8 and $9 \mathrm{~m}$ ) were measured on site using the thermocouple sensors and recorded every 15 min with a CR3000 data logger (Campbell Scientific Australia, Garbutt, Australia) from September to December in 2013 and from March to December in 2014.

\subsection{Water Quality Analysis}

Water samples were transported and kept at $4{ }^{\circ} \mathrm{C}$ during shipping and storage. Reclaimed water, river water, interstitial water and groundwater samples were analyzed for $\mathrm{NO}_{3}-\mathrm{N}_{1} \mathrm{NH}_{4}-\mathrm{N}$, and chemical oxygen demand (COD), $\mathrm{pH}$, electrical conductivity (EC), and dissolved oxygen (DO). All samples were filtered by membrane filter (pore size $0.2 \mu \mathrm{m}$, H9059, Heng Odd, Beijing, China) prior to analysis. Concentrations of $\mathrm{NO}_{3}-\mathrm{N}$ and $\mathrm{NH}_{4}-\mathrm{N}$ were measured colorimetrically using a spectrophotometer (JH756 UV/Vis spectrophotometer, Shanghai, China). COD was analyzed using the spectrophotometer method (DR/2400 spectrophotometer, Loveland, CO, USA) [31]. DO in the water was measured on site with a Sension6 dissolved oxygen meter (Dr. Lange, Berlin, Germany). The $\mathrm{pH}$ was measured by a pH meter (PHB-4, Rex, Shanghai, China) at field condition. EC was measured by an electrical conductivity meter (DDS-307, Rex, Shanghai, China). The on-site parameter temperature, $\mathrm{pH}$, and $\mathrm{DO}$ were detected during sampling. The removal efficiency for each pollutant is expressed as the concentration difference between different locations, e.g., the concentration difference between surface water and interstitial water, surface water and groundwater.

\subsection{Statistical Analysis}

With the statistical analysis, the concentration values of the water quality parameters below the detection limit $\left(\mathrm{NH}_{4}-\mathrm{N}, 0.05 \mathrm{mg} / \mathrm{L}, \mathrm{NO}_{3}-\mathrm{N}, 2 \mathrm{mg} / \mathrm{L}, \mathrm{COD}, 5 \mathrm{mg} / \mathrm{L}\right)$ were treated as the values of the detection limit. Statistical analysis was performed using the non-parametric test with SPSS 18.0 (SPSS Inc., Chicago, IL, USA). The Kruskal-Wallis test (unpaired) was used to determine whether differences existed among parameter concentrations at different sampling locations. A significant 
difference $(p<0.05)$ in the $p$-value indicates a change in parameter concentration at different locations, whereas no significant difference among the data sets was found for cases where $p \geq 0.05$.

\section{Results and Discussion}

\subsection{Groundwater Flow Conditions}

Figure 4 shows the changing pattern of river water and groundwater temperature from 25 September to 15 October 2014. As shown in Figure 4, the river water temperature decreased with time, corresponding to the air temperature from September to October. The groundwater temperature was much lower than the river water in this period, and the groundwater temperature decreased with the increased depth in the same sampling well. The groundwater temperature varied sinusoidally with time, which was similar to that of the river water temperature (see Figure 4), indicating groundwater recharge from the river.

The infiltration rate was estimated about $6.6 \mathrm{~m}^{3} /($ day $\cdot \mathrm{m})$, using the stable seepage from river equation [32]:

$$
q=k(B+A h)
$$

where $q$ is the infiltration rate per unit river channel $\left(\mathrm{m}^{3} /(\right.$ day $\left.\cdot \mathrm{m})\right) ; k$ is the permeability coefficient of the river bank (m/day), $k=0.31 \mathrm{~m} / \mathrm{d}$; $B$ is the river width $(\mathrm{m}), B=17 \mathrm{~m} ; h$ is the river depth $(\mathrm{m}), h=1.7 \mathrm{~m}$; and $A$ is the dimensionless coefficient, $A=2.5$, which is estimated using groundwater dynamics.

The travel time of the flow path was estimated using groundwater levels obtained from the observation wells. The travel time was around 3, 10 and 30 days from river to groundwater well SW1, SW2 and SW3, respectively.

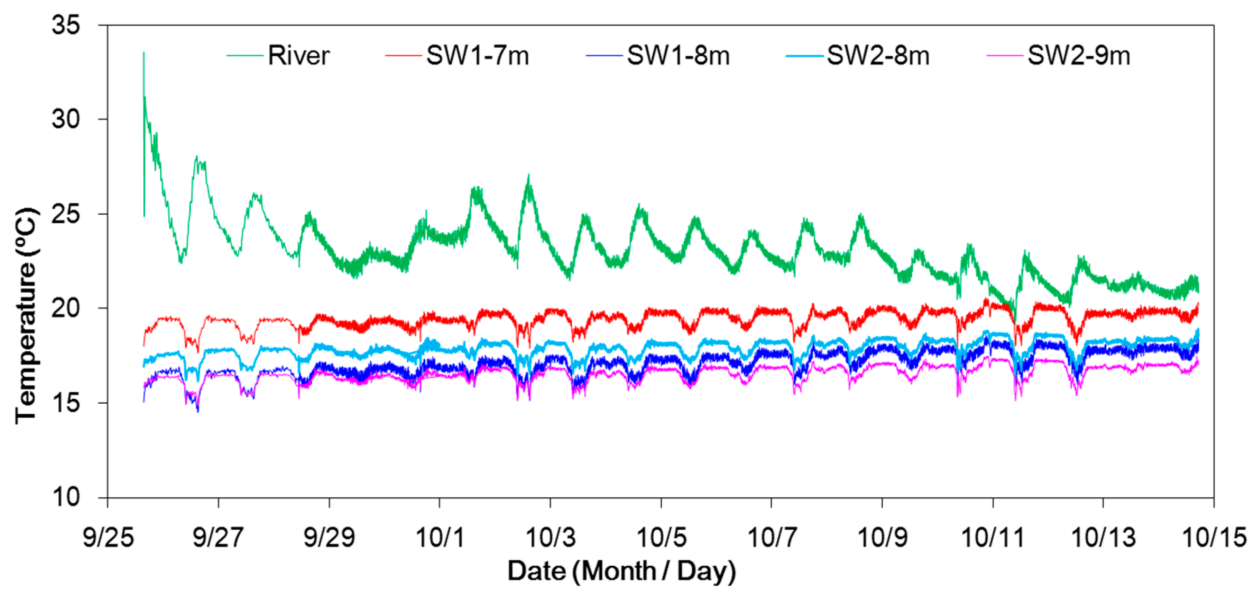

Figure 4. River water temperature and groundwater temperature from 25 September to 15 October 2014 at the depths of 7 and $8 \mathrm{~m}$ of sampling well 1 (SW1-7 $\mathrm{m}$ and SW1-8 m), and at the depths of 8 and $9 \mathrm{~m}$ of sampling well 2 (SW2-8 $\mathrm{m}$ and SW2-9 m).

\subsection{Attenuation of Nitrogen and COD through the RBF System}

\subsubsection{Water Quality of River Water and Reclaimed Water}

The concentration of $\mathrm{NO}_{3}-\mathrm{N}, \mathrm{NH}_{4}-\mathrm{N}, \mathrm{COD}$, total phosphorus (TP) and total nitrogen (TN) in the reclaimed water and river water is shown in Table 2. The results indicate that the river water quality was obviously affected by reclaimed water. As shown in Figure 5, the concentration of $\mathrm{NO}_{3}-\mathrm{N}$, $\mathrm{NH}_{4}-\mathrm{N}$ and COD in the river water changed with the seasons. The $\mathrm{NO}_{3}-\mathrm{N}$ concentration in summer $(10.8 \mathrm{mg} / \mathrm{L})$ was lower than that $(13.9 \mathrm{mg} / \mathrm{L})$ in winter. A similar variation trend was found in the $\mathrm{NH}_{4}-\mathrm{N}$ concentration, $0.4 \mathrm{mg} / \mathrm{L}$ in summer and $0.5 \mathrm{mg} / \mathrm{L}$ in winter, and in the COD concentration, 
$15.7 \mathrm{mg} / \mathrm{L}$ in summer and $25.8 \mathrm{mg} / \mathrm{L}$ in winter. The difference in river water quality between summer and winter was attributed to the reclaimed water quality.

Table 2. Water quality of river water and reclaimed water in 2014.

\begin{tabular}{|c|c|c|c|c|c|c|}
\hline Parameters & Date & $\mathrm{NO}_{3}-\mathrm{N}(\mathrm{mg} / \mathrm{L})$ & $\mathrm{NH}_{4}-\mathrm{N}(\mathrm{mg} / \mathrm{L})$ & COD (mg/L) & TP (mg/L) & $\mathrm{TN}(\mathrm{mg} / \mathrm{L})$ \\
\hline \multirow{10}{*}{$\begin{array}{l}\text { Concentration } \\
\text { (River water) }\end{array}$} & 14 March & 13.6 & 0.3 & 22.8 & - & - \\
\hline & 14 April & 9.5 & 0.3 & 22.5 & 0.2 & 16.6 \\
\hline & 14 May & 8.3 & 0.5 & 26.3 & 0.7 & 13.4 \\
\hline & 14 June & 10.4 & 0.4 & 16.9 & 0.1 & 14.1 \\
\hline & 14 July & 11.4 & 0.3 & 14.9 & 0.1 & 13.4 \\
\hline & 14 August & 14.5 & 0.3 & 15.7 & 0.1 & 15.1 \\
\hline & 14 September & 14.5 & 0.4 & 21.0 & 0.1 & 13.2 \\
\hline & 14 October & 14.6 & 0.2 & 25.7 & 0.1 & 14.3 \\
\hline & 14 November & 17.8 & 0.3 & 32.5 & - & 12.5 \\
\hline & 14 December & 12.4 & 0.4 & 38.5 & - & - \\
\hline \multirow{10}{*}{$\begin{array}{l}\text { Concentration } \\
\text { (Reclaimed water) }\end{array}$} & 14 March & - & - & - & - & - \\
\hline & 14 April & 14.8 & 0.2 & 19.6 & 0.5 & 12.2 \\
\hline & 14 May & 12.5 & 0.4 & 20.6 & 1.0 & 9.0 \\
\hline & 14 June & 11.4 & 0.2 & 18.9 & 0.3 & 11.1 \\
\hline & 14 July & 12.8 & 0.2 & 11.6 & 0.3 & 10.6 \\
\hline & 14 August & 15.9 & 0.1 & 9.1 & 0.1 & 13.0 \\
\hline & 14 September & 14.9 & 0.3 & 11.6 & 0.1 & 12.5 \\
\hline & 14 October & 15.6 & 0.1 & 12.6 & 0.4 & 14.3 \\
\hline & 14 November & 18.9 & 0.2 & 18.5 & - & 11.8 \\
\hline & 14 December & - & - & - & - & - \\
\hline
\end{tabular}

Note: - means no data.
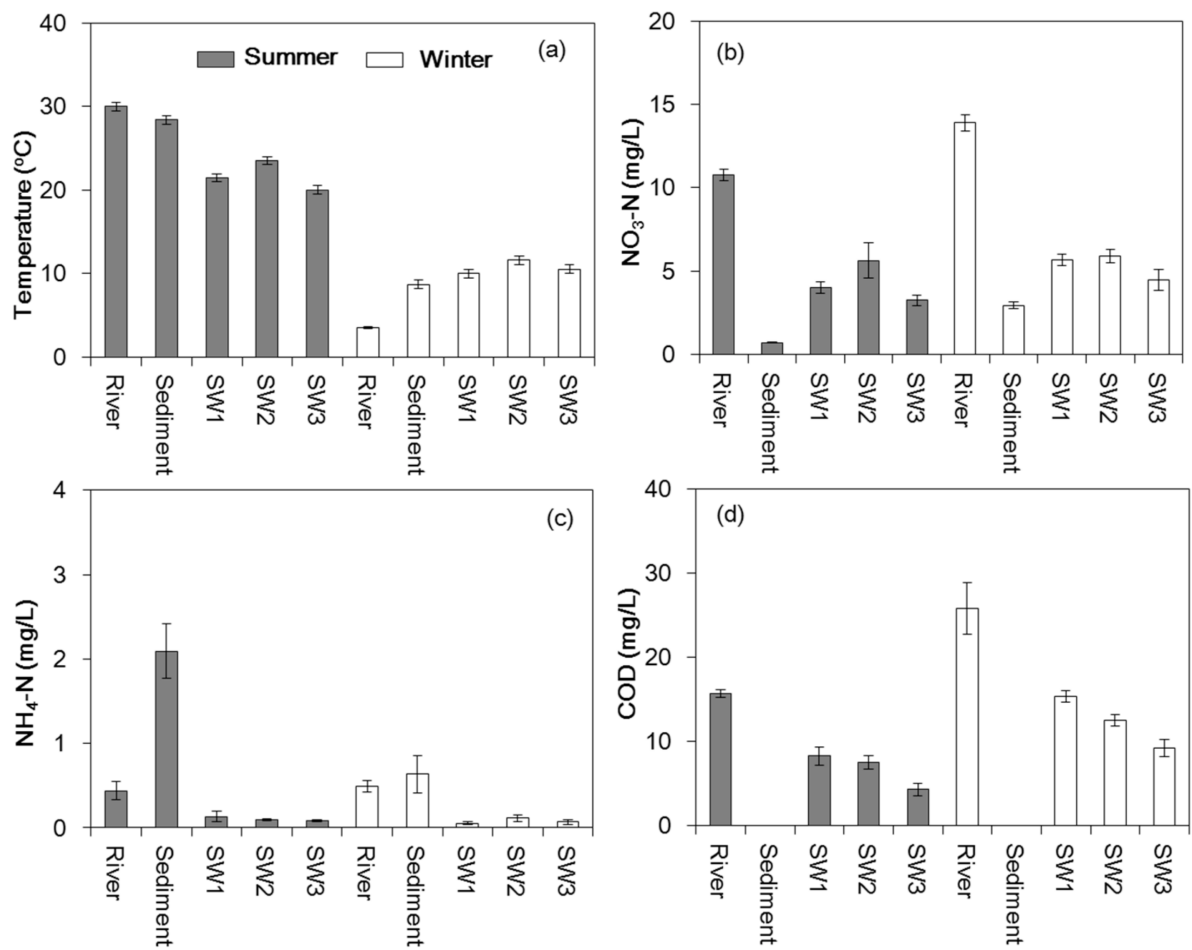

Figure 5. Mean temperature (a), $\mathrm{NO}_{3}-\mathrm{N}(\mathbf{b}), \mathrm{NH}_{4}-\mathrm{N}$ (c), and chemical oxygen demand (COD) (d), in river water, interstitial water and shallow groundwater in the three sampling wells (SW1, SW2, SW3) for the summer $(n=15)$ and winter months $(n=15)$ of 2014.

\subsubsection{Removal of $\mathrm{NO}_{3}-\mathrm{N}$}

The $\mathrm{NO}_{3}-\mathrm{N}, \mathrm{NH}_{4}-\mathrm{N}$ and $\mathrm{COD}$ concentrations in the interstitial water and groundwater during summer and winter of 2014 are presented in Figure 5. Seasonal time periods for the site were defined as periods of uniform temperature during the summer and winter months. As shown in Figure 5b, the $\mathrm{NO}_{3}-\mathrm{N}$ concentrations decreased significantly from $10.8 \mathrm{mg} / \mathrm{L}$ in the river water to $0.7 \mathrm{mg} / \mathrm{L}$ in the 
interstitial water during the summer, and from 13.9 to $2.9 \mathrm{mg} / \mathrm{L}$ during the winter. Correspondingly, $93 \%$ and $79 \%$ of $\mathrm{NO}_{3}-\mathrm{N}$ was removed during the infiltration of river water into sediment during summer and winter, respectively. Similarly, the DO was almost completely consumed in the sediment, dropping to $<1 \mathrm{mg} / \mathrm{L}$ during infiltration. This result is consistent with that of Tufenkji et al. [33], who found that the concentrations of dissolved oxygen are highest in the overlying river water and decrease with depth in the sediment. Meanwhile, the decrease in the $\mathrm{NO}_{3}-\mathrm{N}$ concentration of interstitial water to $<2 \mathrm{mg} / \mathrm{L}$ (Figure $5 \mathrm{~b}$ ) indicates anoxic or even anaerobic conditions with considerable consumption of DO.

$\mathrm{NO}_{3}-\mathrm{N}$ is highly soluble and easily transported from river water to the underlying sediment. In terms of a mass balance, according to Metcalf and Eddy [34], $1 \mathrm{~g}$ of DO is consumed as the electron acceptor for removing one gram of COD. In fact, the consumed DO along the infiltrating path was not enough for the removal of COD according to the mass balance. DO only accounted for around $37 \%$ of the total electron acceptor needed by COD removal during infiltration from the river to the groundwater. Thus, other electron acceptors were required in addition to oxygen. As previously discussed, most of the $\mathrm{NO}_{3}-\mathrm{N}$ was consumed within the riverbed sediment. DO concentration increased from the sediment to the groundwater, indicating that $\mathrm{NO}_{3}-\mathrm{N}$ was continuously consumed as the electron acceptor in the sediment zone. While the increase of $\mathrm{NO}_{3}-\mathrm{N}$ during the infiltration in the zone of river bank was due to nitrification, which was proved by the reduction of $\mathrm{NH}_{4}-\mathrm{N}$ concentration with a DO concentration higher than $2 \mathrm{mg} / \mathrm{L}$. During this process, the $\mathrm{NO}_{3}-\mathrm{N}$ could act as the electron acceptor and denitrification was the main process for $\mathrm{NO}_{3}-\mathrm{N}$ removal in the sediment [35], leading to a higher $\mathrm{NO}_{3}-\mathrm{N}$ removal efficiency. The results suggest that the sediment is an effective barrier against $\mathrm{NO}_{3}-\mathrm{N}$ when river water recharges the groundwater.

The average temperature of the river and interstitial water in the Qingyang River was about 30 and $28^{\circ} \mathrm{C}$ during the summer, and 3.5 and $8.7^{\circ} \mathrm{C}$, in the winter, respectively (Figure 5a). Although the $\mathrm{NO}_{3}-\mathrm{N}$ concentrations in river water were considerably lower during the summer than in the winter, the $\mathrm{NO}_{3}-\mathrm{N}$ removal efficiency through the filtration of sediment was higher in summer than in winter. This can probably be attributed to the temperature variation. Nonetheless, denitrification processes can occur anywhere in the range of $2-50^{\circ} \mathrm{C}[36]$, and possibly beyond. Therefore, $\mathrm{NO}_{3}-\mathrm{N}$ might also be removed at relatively low temperatures $\left(5 \pm 5^{\circ} \mathrm{C}\right)$ in wintertime, because bacteria may have evolved to cope with the specific environmental conditions of our study area.

The average $\mathrm{NO}_{3}-\mathrm{N}$ concentrations at different sampling points were significantly different, with $p=0.001$. The average $\mathrm{NO}_{3}-\mathrm{N}$ concentrations in the sampling wells were significantly higher than in the interstitial water $(p<0.05)$, but significantly lower than concentrations in the river water $(p<0.05)$ (Figure 5b). During the summer months, $\mathrm{NO}_{3}-\mathrm{N}$ increased from $0.7 \mathrm{mg} / \mathrm{L}$ in interstitial water to $4.0 \mathrm{mg} / \mathrm{L}$ in the shallow groundwater from SW1 and maintained similar values at subsequent sampling wells (i.e., $5.6 \mathrm{mg} / \mathrm{L}$ in SW2 and $3.2 \mathrm{mg} / \mathrm{L}$ in SW3).

During the infiltration of river water to shallow groundwater, the $\mathrm{NO}_{3}-\mathrm{N}$ removal efficiency was approximately $62 \%$ in SW1, 47\% in SW2, and 69\% in SW3. A similar pattern occurred during the winter where the removal efficiency of $\mathrm{NO}_{3}-\mathrm{N}$ in SW1, SW2, and SW3 were 59\%, 57\%, and 67\%, respectively. The average concentration of DO increased from $0.9 \mathrm{mg} / \mathrm{L}$ in the interstitial water to $>3.0 \mathrm{mg} / \mathrm{L}$ in the surface of shallow groundwater, indicating that the reduction environment was relatively weak at the interface of the unsaturated zone and groundwater, which was also unfavorable to denitrification. In general, denitrification was promoted only when the concentration of DO fell below a certain low threshold (i.e., $<1 \mathrm{mg} / \mathrm{L}$ and perhaps $<2 \mathrm{mg} / \mathrm{L}$ ) $[37,38]$. Therefore, the denitrification rates were reduced on the surface of the shallow groundwater, where DO concentrations exceeded $2 \mathrm{mg} / \mathrm{L}$, leading to the increase of $\mathrm{NO}_{3}-\mathrm{N}$ in the shallow groundwater compared to that of the interstitial water. Nitrification occurred as the water flowed from the sediment to the shallow aquifer, resulting in an increase in $\mathrm{NO}_{3}-\mathrm{N}$ in the groundwater compared to that in the interstitial water. Correspondingly, as shown in Figure $5 \mathrm{c}$, the $\mathrm{NH}_{4}-\mathrm{N}$ concentration was found to decrease during infiltration from the sediment to the groundwater, indicating that $\mathrm{NH}_{4}-\mathrm{N}$ was transformed into $\mathrm{NO}_{3}-\mathrm{N}$. Additionally, 
the mineralization of organic nitrogen in the soil might be partly responsible for the $\mathrm{NO}_{3}-\mathrm{N}$ increase in the shallow groundwater.

\subsubsection{Removal of $\mathrm{NH}_{4}-\mathrm{N}$}

The average $\mathrm{NH}_{4}-\mathrm{N}$ concentrations in the interstitial water were significantly higher than those in the river water and shallow groundwater $(p<0.0 .5)$ (Figure $5 c$ ). Specifically, the concentration of $\mathrm{NH}_{4}-\mathrm{N}$ was $0.4 \mathrm{mg} / \mathrm{L}$ (during summer) and $0.49 \mathrm{mg} / \mathrm{L}$ (during winter) in the river water, and as much as $2.1 \mathrm{mg} / \mathrm{L}$ (during summer) and $0.63 \mathrm{mg} / \mathrm{L}$ (during winter) in the interstitial water, corresponding to increases of around $425 \%$ and $28 \%$ in summer and winter, respectively. The relatively high content of clay (25\%) and organic matter (1.2\%) in the sediment in Qingyang River resulted in a relatively large sediment adsorption capacity. Clay containing abundant organic matter has a high cation-exchange capacity, causing a reduced $\mathrm{NH}_{4}-\mathrm{N}$ releasing flux from the sediment to the river water. In general, $\mathrm{NH}_{4}-\mathrm{N}$ can accumulate in organic-rich sediment under anaerobic conditions through ammonification by heterotrophic bacteria [39-41]. Additionally, nitrification was inhibited in a reduction condition, as the DO concentration in the interstitial water decreased to lower than $1 \mathrm{mg} / \mathrm{L}$. The measurement might be influenced by random error due to limitations of the sampling/analytical procedure.

The average $\mathrm{NH}_{4}-\mathrm{N}$ concentrations decreased from 2 (in interstitial water) to $0.1 \mathrm{mg} / \mathrm{L}$ (in groundwater) during the summer and from 0.6 to $0.08 \mathrm{mg} / \mathrm{L}$ during the winter. As shown in Figure $5 \mathrm{c}$, there was no obvious difference in $\mathrm{NH}_{4}-\mathrm{N}$ concentrations observed among the three sampling wells. Approximately $95 \%$ of the $\mathrm{NH}_{4}-\mathrm{N}$ was removed as water passed through the sediment to the shallow groundwater during the summer and $88 \%$ during the winter. The $\mathrm{NH}_{4}-\mathrm{N}$ consumption was attributed to a combination of adsorption and a subsequent nitrification process, converting $\mathrm{NH}_{4}-\mathrm{N}$ to $\mathrm{NO}_{3}-\mathrm{N}$ [42], when DO concentrations are higher than $2 \mathrm{mg} / \mathrm{L}$. The nitrification process may partly account for the $\mathrm{NO}_{3}-\mathrm{N}$ increase in the shallow groundwater. The result was consistent with that of Essandoh et al. [37] who found that nitrification yielded high concentrations of $\mathrm{NO}_{3}-\mathrm{N}$ in the effluents during a soil column study.

\subsubsection{Removal of COD}

Average summertime and wintertime COD concentrations in the river water and shallow groundwater are presented in Figure 5d (note that the interstitial water samples were insufficient for COD analysis). In summer, the average COD concentration in the river water was $15.7 \mathrm{mg} / \mathrm{L}$, decreasing to $8.3 \mathrm{mg} / \mathrm{L}$ in the shallow groundwater SW1, with a removal efficiency of $47 \%$. In winter, the average COD concentration decreased from 25.5 to $15.3 \mathrm{mg} / \mathrm{L}$, with a removal efficiency of $40 \%$. The attenuation of organic compounds (as a major driver for COD) was primarily attributed to the combined effects of microbial biodegradation and adsorption onto sediments [43-45]. The COD concentrations continued to decrease in the shallow groundwater with increasing distance from the riverbank (from SW1 to SW3). The COD concentration in SW3 decreased to $4.3 \mathrm{mg} / \mathrm{L}$ in summer and $9.2 \mathrm{mg} / \mathrm{L}$ in winter. This indicates a $72.6 \%$ and $64.2 \%$ removal efficiency for summer and winter, respectively. These results are similar to those of Maeng et al. [23], who found that the removal efficiency of organic matter during bank filtration increased with residence times and travel distances. Lenk et al. [46] also demonstrated that organic matter concentrations are inversely correlated with residence times and travel distances in bank filtration sites. The COD removal efficiency was slightly higher in the summer than in the winter, which was attributed to higher temperatures, improving microbial biological activity. These results also suggest that organics can be removed at temperatures lower than $12{ }^{\circ} \mathrm{C}$. The result is consistent with that of Abel et al. [25] who reported that the cut-off temperature to slow down or inhibit microbial activity on the attenuation of organics in soil-water systems is $5^{\circ} \mathrm{C}$. 


\subsection{Temporal Variations of Nitrogen and COD in Groundwater}

The temporal variation of the $\mathrm{NO}_{3}-\mathrm{N}$ concentration in groundwater at depths of 5,7 , and $9 \mathrm{~m}$ in SW2 in 2014 is shown in Figure 6a. The variation of the $\mathrm{NO}_{3}-\mathrm{N}$ concentrations in the groundwater over time was similar to the river water concentrations. The $\mathrm{NO}_{3}-\mathrm{N}$ concentrations in the groundwater varied obviously over the sampling period. The lowest groundwater $\mathrm{NO}_{3}-\mathrm{N}$ concentrations occurred during the summer, from June to September, whereas the $\mathrm{NO}_{3}-\mathrm{N}$ concentration was relatively high during the period from March to April and from November to December. The seasonal difference in $\mathrm{NO}_{3}-\mathrm{N}$ concentration was highly dependent on denitrification, indicating that the variation of groundwater temperature was one of the important factors affecting denitrification. The groundwater temperature at different sampling depths varied from 8 to $26{ }^{\circ} \mathrm{C}$ during the experiment period (Figure $6 \mathrm{~d}$ ). High temperatures promote biological reaction (denitrification) rates and the rate of oxygen consumption [47]. Oxygen depletion through microbial activity, coupled with decreased oxygen solubility in warmer water, led to reductive conditions that were favorable to denitrification in the RBF system during the summer [20,47]. Higher temperatures and corresponding reductive conditions resulted in greater $\mathrm{NO}_{3}-\mathrm{N}$ removal during the summer than during the winter in the groundwater environment. The increase in denitrification with increasing temperature has been previously reported. Saunders and Kalff [48] reported that a $5{ }^{\circ} \mathrm{C}$ increase in temperature results in a ten-fold increase in the denitrification rate. In this study, as shown in Figure 7, the $\mathrm{NO}_{3}-\mathrm{N}$ removal efficiency increased with the groundwater temperature at an exponential function with the determination values $\left(R^{2}\right) 0.744,0.811$, and 0.564 , at depths of 5,7 , and $9 \mathrm{~m}$, respectively.
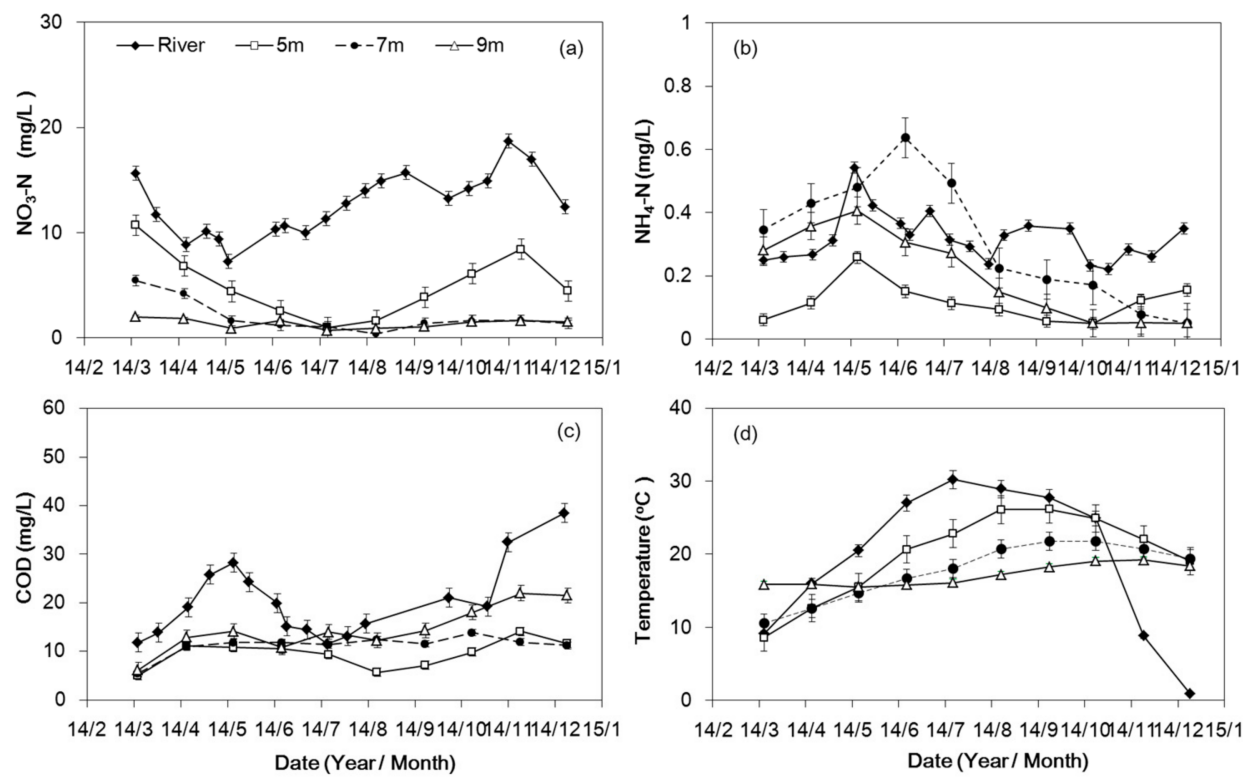

Figure 6. Temporal variations in average $\mathrm{NO}_{3}-\mathrm{N}(\mathbf{a}), \mathrm{NH}_{4}-\mathrm{N}(\mathbf{b})$, chemical oxygen demand (COD) (c) and temperature (d), in river water and groundwater at depths of 5, 7, and $9 \mathrm{~m}$ of SW2 in 2014.

Figure $6 \mathrm{~b}$ depicts the temporal variation of $\mathrm{NH}_{4}-\mathrm{N}$ concentrations in the groundwater in 2014 . The $\mathrm{NH}_{4}-\mathrm{N}$ concentrations in the groundwater varied widely over the sampling period. $\mathrm{Th} \mathrm{NH}_{4}-\mathrm{N}$ concentration increased from March to May at 5 and $9 \mathrm{~m}$ depth, with a temperature range from $8-16{ }^{\circ} \mathrm{C}$ (Figure $6 \mathrm{~b}, \mathrm{~d}$ ). The $\mathrm{NH}_{4}-\mathrm{N}$ concentration at $7 \mathrm{~m}$ depth increased from $0.35 \mathrm{mg} / \mathrm{L}$ in March to $0.64 \mathrm{mg} / \mathrm{L}$ in June, which exceeded the drinking water standard $(<0.5 \mathrm{mg} / \mathrm{L}$ in China). This suggests that the $\mathrm{NH}_{4}-\mathrm{N}$ concentration in groundwater increased with groundwater temperature when the groundwater temperature was from $8-16^{\circ} \mathrm{C}$. The increase in the $\mathrm{NH}_{4}-\mathrm{N}$ concentration was mainly attributed to the mineralization of organic nitrogen. The increase in temperature enhanced the mineralization 
potential [25]. Several field studies [49-51] also found that $\mathrm{NH}_{4}-\mathrm{N}$ originated from degrading in situ organic matter in the soil.

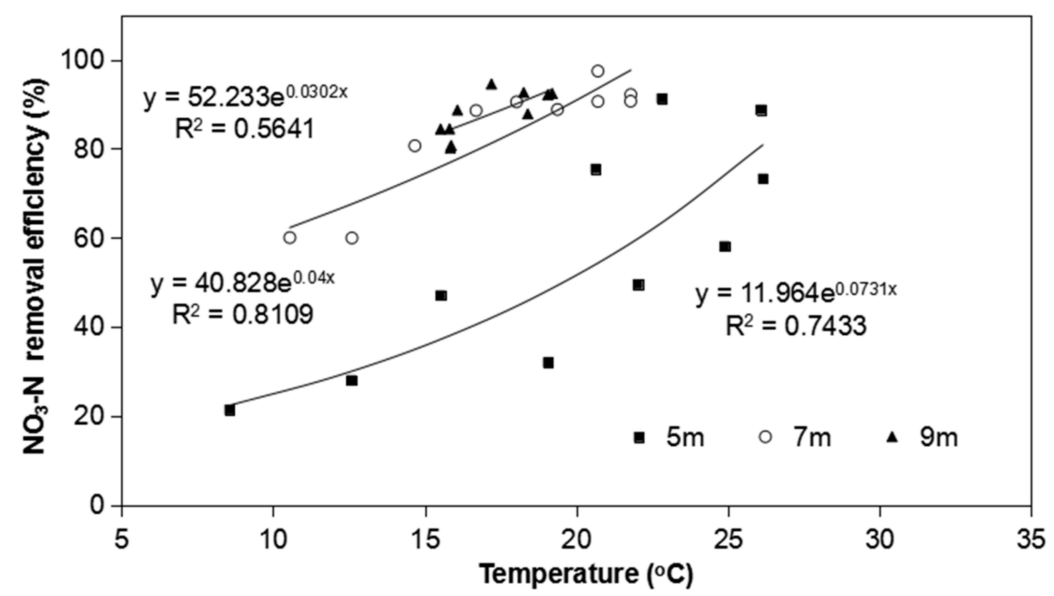

Figure 7. The relationship between $\mathrm{NO}_{3}-\mathrm{N}$ removal efficiency and groundwater temperature.

The ammonium concentration began to decline in July at three sampling depths with groundwater temperatures within a range of $20-26{ }^{\circ} \mathrm{C}$ (Figure $6 \mathrm{~b}$ ). In general, nitrification is unlikely to occur in the saturated zone with an anaerobic environment. Therefore, the decrease of $\mathrm{NH}_{4}-\mathrm{N}$ in the groundwater may be attributed to the dissociation of $\mathrm{NH}_{4}-\mathrm{N}$ to ammonia. $\mathrm{Li}$ et al. [52] found that $\mathrm{NH}_{4}-\mathrm{N}$ can deprotonate to ammonia in conditions with a $\mathrm{pH}$ value larger than 6 , and the ammonia product can degas, particularly with water temperatures in a range of $19-27^{\circ} \mathrm{C}$. In this study, the $\mathrm{pH}$ range was from 6.7 to 8.1 in the groundwater. Under such conditions, $\mathrm{NH}_{4}-\mathrm{N}$ is likely to be degassed by a reaction of $\mathrm{NH}_{4}{ }^{+}$(aq) $-\mathrm{NH}_{3}(\mathrm{aq})-\mathrm{NH}_{3}$ (g) and emitted from the groundwater to the unsaturated pore space [53]. However, the $\mathrm{NH}_{4}-\mathrm{N}$ in the groundwater cannot be depleted completely, which is possibly explained by a release of $\mathrm{NH}_{4}-\mathrm{N}$ from organic material that balances the loss of ammonia.

The temporal variation of COD concentrations is presented in Figure 6c. The COD concentrations varied with time and showed similar variation trends at different depths. The COD concentration range was between 5.0-22.0 mg/L for three depths, which was always lower than that in the river water, which had a range of $12.8-38.5 \mathrm{mg} / \mathrm{L}$. As shown in Figure $6 \mathrm{c}, \mathrm{d}$, the groundwater temperature varied from $8.5-26.4{ }^{\circ} \mathrm{C}$ and it did not show a significant influence on the variation of COD concentration. In contrast, Abel et al. [25] carried out a laboratory experiment and found that the dissolved oxygen carbon removal increased by $10 \%$ for every $5{ }^{\circ} \mathrm{C}$ increase in temperature over a range of $15-25{ }^{\circ} \mathrm{C}$, whereas Hoppe-Jones et al. [24] reported that the total organic carbon concentration in the monitoring well of a RBF system was independent of season, with temperatures varying from $7-19{ }^{\circ} \mathrm{C}$. Possemiers et al. [54] also found that temperature had hardly any effect on organic matter in groundwater when the groundwater temperature change was lower than $15^{\circ} \mathrm{C}$. In this study, the results indicate that there was no seasonal variation in COD concentration when the temperature difference was around $18^{\circ} \mathrm{C}$, that is, when the groundwater temperature varied from $8.5-26.5^{\circ} \mathrm{C}$.

\subsection{Vertical Distribution of Nitrogen and $C O D$}

Figure 8 shows the average annual $\mathrm{NO}_{3}-\mathrm{N}, \mathrm{NH}_{4}-\mathrm{N}$ and $\mathrm{COD}$ concentrations in the groundwater at depths of 4-9 m during the three year period. The vertical distribution of the $\mathrm{NO}_{3}-\mathrm{N}$ concentration in 2014 was higher than in the other two experimental years due to the relatively high $\mathrm{NO}_{3}-\mathrm{N}$ concentration in river water. The $\mathrm{NO}_{3}-\mathrm{N}$ concentration decreased with depth in the saturated zone (Figure 8a). At $9 \mathrm{~m}$ depth, the $\mathrm{NO}_{3}-\mathrm{N}$ concentration was 1.1, 1.3, and $0.4 \mathrm{mg} / \mathrm{L}$ in 2013, 2014, and 2015, respectively. These values are much lower than the threshold for the quality standard of drinking water (10 mg/L for China). It should be noted that $\mathrm{NO}_{3}-\mathrm{N}$ removal by denitrification mainly occurred 
at depths of 4-7 $\mathrm{m}$ for three years. Variations of $\mathrm{NO}_{3}-\mathrm{N}$ concentration at different depths are related to the corresponding soil textures. As shown in Table 1, the soil texture at the depths of 3.6-5.2 m and $6.5-7.5 \mathrm{~m}$ is silt loam, which causes a full denitrification process with lower saturated hydraulic conductivity and longer hydraulic retention time. The relatively high organic content (Table 1) at depths of 3.6-5.2 $\mathrm{m}$ and 6.5-7.5 $\mathrm{m}$ also resulted in an obvious $\mathrm{NO}_{3}-\mathrm{N}$ reduction in the saturated zone. This is consistent with the previous findings of Krause et al. [55] and Barnes et al. [56], who indicated that the denitrification rates and $\mathrm{NO}_{3}-\mathrm{N}$ concentrations are related to the availability of oxidizable labile organic carbon.
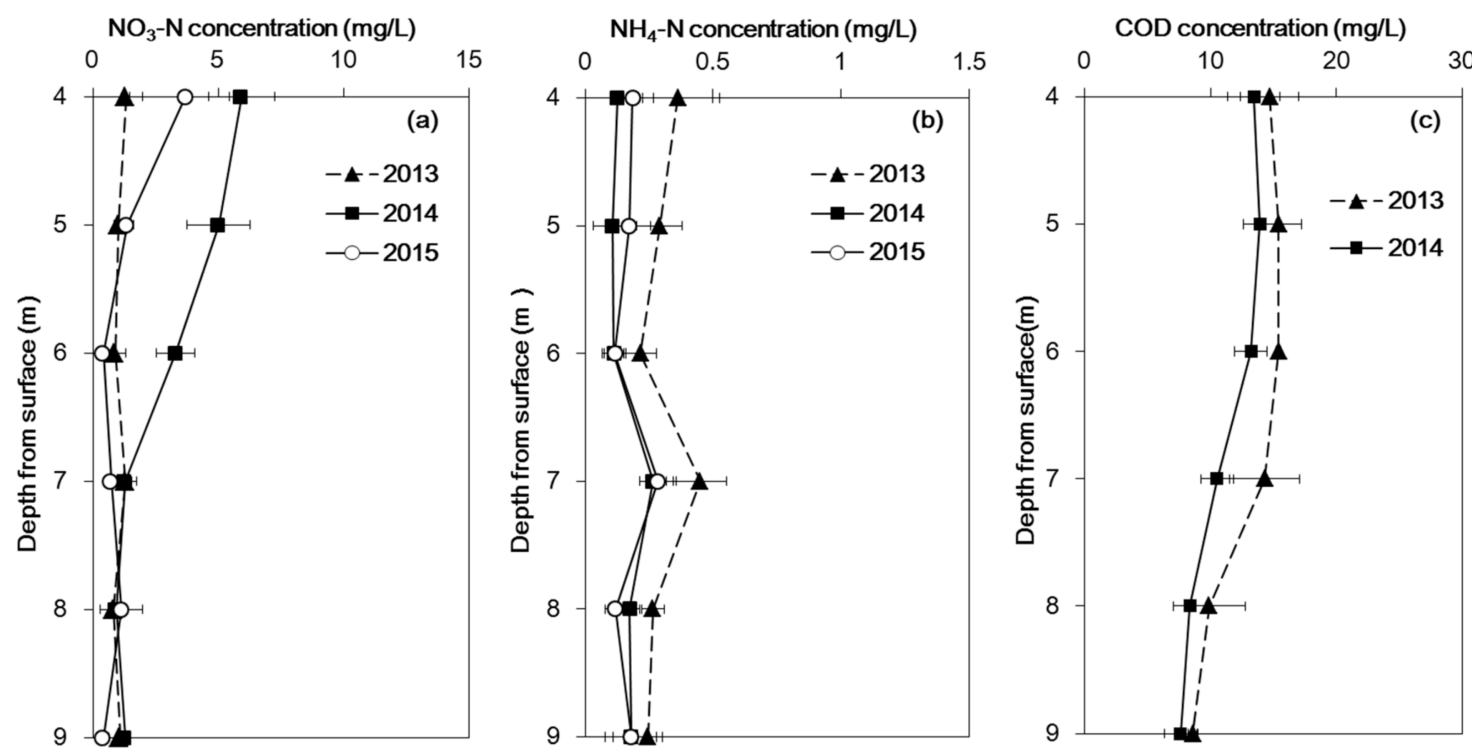

Figure 8. Vertical distributions of annual mean $\mathrm{NO}_{3}-\mathrm{N}(\mathbf{a}), \mathrm{NH}_{4}-\mathrm{N}(\mathbf{b})$ and chemical oxygen demand (COD) (c), in the groundwater in 2013, 2014 and 2015.

As shown in Figure $8 \mathrm{~b}$, the average $\mathrm{NH}_{4}-\mathrm{N}$ concentration varied with depth in the saturated zone. The $\mathrm{NH}_{4}-\mathrm{N}$ concentration profiles presented a similar change pattern for the three years. The $\mathrm{NH}_{4}-\mathrm{N}$ concentration in 2013 was higher than the other years, which was probably due to the relatively high $\mathrm{NH}_{4}-\mathrm{N}$ concentration in river water. A relatively high $\mathrm{NH}_{4}-\mathrm{N}$ concentration can be found at depths of 6-7 m. This may be attributed to the mineralization of organic nitrogen. As shown in Table 1, the relatively large amounts of organic contents found in the saturated zone at depths of 6.5-7.5 m may have led to the increase in $\mathrm{NH}_{4}-\mathrm{N}$ concentration. A similar result was found by Jiao et al. [50], who reported that the large amount of total organic carbon in the aquitard is favorable for organic nitrogen mineralization. They also found that organic nitrogen can convert to $\mathrm{NH}_{4}-\mathrm{N}$ in the aquitard. The results showed that the soil texture and organic contents varied at different depths, leading to variations of $\mathrm{NH}_{4}-\mathrm{N}$ concentration with depth in the saturated zones.

The average annual vertical distribution of the COD concentration in 2013 and 2014 is presented in Figure 8c. The COD concentration decreased with depth from $14.7 \mathrm{mg} / \mathrm{L}$ at $4 \mathrm{~m}$ to $8.6 \mathrm{mg} / \mathrm{L}$ at $9 \mathrm{~m}$ in 2013, and from $13.5 \mathrm{mg} / \mathrm{L}$ at $4 \mathrm{~m}$ to $7.6 \mathrm{mg} / \mathrm{L}$ at $9 \mathrm{~m}$ in 2014. Compared with the river water, a removal efficiency of 58.6\% in 2013 and $54.6 \%$ in 2014 was found for COD at $9 \mathrm{~m}$ through the RBF system. Possible mechanisms for COD removal include adsorption and biodegradation during river bank filtration [25,57]. These results suggest that the RBF system is effective in COD reduction. Previous laboratory and field studies $[37,57,58]$ have reported similar results. For example, Wang et al. [59] found that about $48-51 \%$ of the COD was removed in a laboratory column experiment. In this study, in the upper part of the shallow groundwater, the COD concentration increased slightly from 4 to $5 \mathrm{~m}$. The COD concentration decreased with depth in the saturated zone (from 5 to $9 \mathrm{~m}$ ). Different variations were attributed to the variable redox conditions under various hydrogeochemical 
environments. This implies that further study is required to investigate the oxidation-reduction potential at different depths in the saturated zone in this study area.

\section{Conclusions}

Three-year field datasets were collected and analyzed to investigate the effect of RBF on the removal of the nitrogen and organic contaminants in the Qingyang River of Beijing. The following conclusions can be drawn:

(1) The seasonal variation exhibited an improved attenuation between winter and summer operations. A high $\mathrm{NO}_{3}-\mathrm{N}$ removal efficiency $(85 \%)$ was obtained through $\mathrm{RBF}$ at high temperatures $\left(27^{\circ} \mathrm{C}\right)$ during the summer season in Beijing.

(2) An average $54 \%$ of COD was removed through RBF. Temperature does not show a significant effect on COD removal by the RBF, whereas COD removal increases with the retention time and/or travel distance in the RBF system.

(3) The study indicates that the RBF system is an effective barrier removing $\mathrm{NO}_{3}-\mathrm{N}, \mathrm{NH}_{4}-\mathrm{N}$ and COD in the Qingyang River. As the river was refilled with reclaimed waste water, the potential contamination risk of $\mathrm{NO}_{3}-\mathrm{N}$ and COD for the shallow groundwater near the Qingyang River was relatively low during the monitoring period. However, long-term field observations and assessments of the RBF performance are needed to consider the safe reuse of reclaimed waste water in rivers for managed aquifer recharge. These should also include other variables such as micropollutants, the importance of travel time and general groundwater flow conditions.

Acknowledgments: This research was supported by the National Key Research and Development Project (Grant number: 2016YFC0501304) and National Natural Science Foundation of China (Grant numbers: $51639009,51779256)$.

Author Contributions: Quanzhong Huang and Weiyan Pan conceived and designed the experiments; Weiyan Pan performed the experiment, analyzed the data, and wrote the paper; Guanhua Huang and Quanzhong Huang corrected and improved it.

Conflicts of Interest: The authors declare no conflicts of interest.

\section{References}

1. Chu, J.Y.; Chen, J.N.; Wang, C.; Fu, P. Wastewater reuse potential analysis: Implications for China's water resources management. Water Res. 2004, 38, 2746-2756. [CrossRef] [PubMed]

2. Yu, Y.L.; Song, X.F.; Zhang, Y.H.; Zheng, F.D.; Liu, L.C. Impact of reclaimed water in the watercourse of Huai River on groundwater from Chaobai River basin, Northern China. Front. Earth Sci. 2017, 11, 643-659. [CrossRef]

3. Ernst, M.; Sperlich, A.; Zheng, X.; Gan, Y.; Hu, J.; Zhao, X.; Wang, J.; Jekel, M. An integrated wastewater treatment and reuse concept for the Olympic Park 2008, Beijing. Desalination 2007, 202, 293-301. [CrossRef]

4. Fan, Q.; Liu, W.; Jiao, Z; Sun, F. Beijing Water Resources Bulletin; Beijing Hydrological Station: Beijing, China, 2015.

5. Huang, X.R.; Xiong, W.; Liu, W.; Guo, X.Y. Effect of reclaimed water effluent on bacterial community structure in the Typha angustifolia L. rhizosphere soil of urbanized riverside wetland, China. J. Environ. Sci. 2017, 55, 58-68. [CrossRef] [PubMed]

6. Chen, W.P.; Lu, S.D.; Jiao, W.T.; Wang, M.E.; Chang, A.C. Reclaimed water: A safe irrigation water source? Environ. Dev. 2013, 8, 74-83. [CrossRef]

7. Ray, C.; Grischek, T.; Schubert, J.; Wang, J.Z.; Speth, T.F. A perspective of riverbank filtration. J. Am. Water Works Assoc. 2002, 94, 149-160. [CrossRef]

8. Tyagi, S.; Dobhal, R.; Kimothi, P.C.; Adlakha, L.K.; Singh, P.; Uniyal, D.P. Studies of river water quality using river bank filtration in Uttarakhand, India. Water Qual. Expo. Health 2013, 5, 139-148. [CrossRef]

9. Voeroesmarty, C.J.; McIntyre, P.B.; Genssner, M.O.; Dudgeon, D.; Prusevich, A.; Green, P.; Bunn, E.S.; Sullivan, A.C.; Liermann, R.C.; Davies, M.P. Global threats to human water security and river biodiversity. Nature 2010, 467, 555-561. [CrossRef] [PubMed]

10. Ray, C. Worldwide potential of riverbank filtration. Clean Tech. Environ. Policy 2008, 10, 223-225. [CrossRef]

11. Schiermeier, Q. Water on tap. Nature 2014, 510, 326-328. [CrossRef] [PubMed] 
12. Hu, B.; Teng, Y.G.; Zhai, Y.Z.; Zuo, R.; Li, J.; Chen, H.Y. Riverbank filtration in China: A review and perspective. J. Hydrol. 2016, 541, 914-927. [CrossRef]

13. Hiscock, K.M.; Grischek, T. Attenuation of groundwater pollution by bank filtration. J. Hydrol. 2002, 266, 139-144. [CrossRef]

14. Hayakawa, A.; Ikeda, S.; Tsushima, R.; Ishikawa, Y.; Hidaka, S. Spatial and temporal variations in nutrients in water and riverbed sediments at the mouths of rivers that enter Lake Hachiro, a shallow eutrophic lake in Japan. Catena 2015, 133, 486-494. [CrossRef]

15. Maeng, S.K.; Sharma, S.K.; Lekkerkerker-Teunissen, K.; Amy, G.L. Occurrence and fate of bulk organic matter and pharmaceutically active compounds in managed aquifer recharge: A review. Water Res. 2011, 45, 3015-3033. [CrossRef] [PubMed]

16. Carrey, R.; Rodriguez-Escales, P.; Otero, N.; Ayora, C.; Soler, A.; Gómez-Alday, J.J. Nitrate attenuation potential of hypersaline lake sediments in central Spain: Flow-through and batch experiments. J. Contam. Hydrol. 2014, 164, 323-337. [CrossRef] [PubMed]

17. Herrman, K.S.; Bouchard, V.; Moore, R.H. Factors affecting denitrification in agricultural headwater streams in Northeast Ohio, USA. Hydrobiologia 2008, 598, 305-314. [CrossRef]

18. Laverman, A.M.; Garnier, J.A.; Mounier, E.M.; Roose-Amsaleg, C.L. Nitrous oxide production kinetics during nitrate reduction in river sediments. Water Res. 2010, 44, 1753-1764. [CrossRef] [PubMed]

19. Grischek, T.; Hiscock, K.M.; Metschies, T.; Dennis, P.F.; Nestler, W. Factors affecting denitrification during infiltration of river water into a sand and gravel aquifer in Saxony, Germany. Water Res. 1998, 32, 450-460. [CrossRef]

20. Filter, J.; Jekel, M.; Ruhl, A.S. Impacts of accumulated particulate organic matter on oxygen consumption and organic micro-pollutant elimination in bank filtration and soil aquifer treatment. Water 2017, 9, 349. [CrossRef]

21. Schoenheinz, D.; Grischek, T. Behavior of Dissolved Organic Carbon During Bank Filtration under Extreme Climate Conditions; Springer: Dordrecht, The Netherlands, 2011; pp. 51-67. [CrossRef]

22. Bertelkamp, C.; Verliefde, A.R.D.; Schoutteten, K.; Vanhaecke, L.; Vanden, B.J.; Singhal, N.; van der Hoek, J.P. The effect of redox conditions and adaptation time on organic micropollutant removal during river bank filtration: A laboratory-scale column study. Sci. Total Environ. 2016, 544, 309-318. [CrossRef] [PubMed]

23. Maeng, S.K.; Ameda, E.; Sharma, S.K.; Grützmacher, G.; Amy, G.L. Organic micropollutant removal from wastewater effluent-impacted drinking water sources during bank filtration and artificial recharge. Water Res. 2010, 44, 4003-4014. [CrossRef] [PubMed]

24. Hoppe-Jones, C.; Oldham, G.; Drewes, J.E. Attenuation of total organic carbon and unregulated trace organic chemicals in U.S. riverbank filtration systems. Water Res. 2010, 44, 4643-4659. [CrossRef] [PubMed]

25. Abel, C.D.T.; Sharma, S.K.; Malolo, Y.N.; Maeng, S.K.; Kennedy, M.D.; Amy, G.L. Attenuation of bulk organic matter, nutrients ( $\mathrm{N}$ and $\mathrm{P}$ ), and pathogen indicators during soil passage: Effect of temperature and redox conditions in simulated soil aquifer treatment (SAT). Water Air Soil Pollut. 2014, 223, 5205-5220. [CrossRef]

26. Grünheid, S.; Amy, G.; Jekel, M. Removal of bulk dissolved organic carbon (DOC) and trace organic compounds by bank filtration and artificial recharge. Water Res. 2005, 39, 3219-3228. [CrossRef] [PubMed]

27. Im, H.; Yeo, I.; Maeng, S.K.; Park, C.H.; Choi, H. Simultaneous attenuation of pharmaceuticals, organic matter, and nutrients in wastewater effluent through managed aquifer recharge: Batch and column studies. Chemosphere 2016, 143, 135-141. [CrossRef] [PubMed]

28. Yang, L.; He, J.T.; Liu, Y.; Wang, J.; Jiang, L.; Wang, G.C. Characteristics of change in water quality along reclaimed water intake area of the Chaobai River in Beijing, China. J. Environ. Sci. 2015, 50, 93-102. [CrossRef] [PubMed]

29. Li, Z.; Xiang, X.; Li, M.; Ma, Y.P.; Wang, J.H.; Liu, X. Occurrence and risk assessment of pharmaceuticals and personal care products and endocrine disrupting chemicals in reclaimed water and receiving groundwater in China. Ecotoxicol. Environ. Saf. 2015, 119, 74-80. [CrossRef] [PubMed]

30. Schaap, M.G.; Leij, F.J.; van Genuchten, M.T. Rosetta: A computer program for estimating soil hydraulic parameters with hierarchical pedotransfer functions. J. Hydrol. 2001, 251, 163-176. [CrossRef]

31. Wei, F.S.; Qi, W.Q.; Sun, Z.G.; Huang, Y.R.; Shen, Y.W. Water and Wastewater Monitoring and Analysis Method; China Environmental Science Press: Beijing, China, 2002; ISBN 978-7-8016-3400-9.

32. Zhang, W.Z. Groundwater and Soil Water Dynamics; China Hydraulic and Power Press: Beijing, China, 1996; ISBN 780-1-2413-04. 
33. Tufenkji, N.; Ryan, J.N.; Elimelech, M. The promise of bank filtration. Environ. Sci. Technol. 2002, 36, 423-428. [CrossRef]

34. Metcalf \& Eddy, Inc. Wastewater Engineering: Treatment and Reuse, 4th ed.; McGraw-Hill Inc.: New York, NY, USA, 2003; ISBN 978-0-0734-0118-8.

35. Brady, N.C.; Weil, R.R. The Nature and Properties of Soils, 13th ed.; Prentice Hall: Upper Saddle River, NJ, USA, 2002; ISBN 13-016763-0.

36. Aelion, C.M.; Shaw, J.N.; Wahl, M. Impact of suburbanization on ground water quality and denitrification in coastal aquifer sediments. J. Exp. Mar. Biol. Ecol. 1997, 213, 31-51. [CrossRef]

37. Essandoh, H.M.K.; Tizaoui, C.; Mohamed, M.H.A. Removal of dissolved organic carbon and nitrogen during simulated soil aquifer treatment. Water Res. 2013, 47, 3559-3572. [CrossRef] [PubMed]

38. Essandoh, H.M.K.; Tizaoui, C.; Mohamed, M.H.A.; Amy, G.; Brdjanovic, D. Soil aquifer treatment of artificial wastewater under saturated conditions. Water Res. 2011, 45, 4211-4226. [CrossRef] [PubMed]

39. DiToro, D. Sediment Flux Modeling; Wiley-Interscience: New York, NY, USA, 2001; ISBN 978-0-47-113535-7.

40. Machesky, M.L.; Holm, T.R.; Shackleford, D.B. Concentrations and Potential Toxicity of Metals and Ammonia in Peoria Lake Sediments and Pore Waters; Illinois State Water Survey Champaign: Champaign, IL, USA, 2004.

41. Wetzel, R.G. Limnology, 2nd ed.; Saunders College: New York, NY, USA, 1983; ISBN 978-0-19-921395-4.

42. Crites, R.; Reed, S.; Bastian, R. Land Treatment Systems for Municipal and Industrial Wastes; McGraw Hill Professional: New York, NY, USA, 2000; ISBN 978-0-07-061040-8.

43. Quanrud, D.M.; Hafer, J.; Karpiscak, M.M.; Zhang, J.M.; Lansey, K.E.; Arnold, R.G. Fate of organics during soil-aquifer treatment: Sustainability of removals in the field. Water Res. 2003, 37, 3401-3411. [CrossRef]

44. Reemtsma, T.; Gnir $\beta$, R.; Jekel, M. Infiltration of combined sewer overflow and tertiary municipal wastewater: An integrated laboratory and field study on nutrients and dissolved organics. Water Res. 2000, 34, 1179-1186. [CrossRef]

45. Zhang, Z.Y.; Lei, Z.F.; Zhang, Z.Y.; Sugiura, N.; Xu, X.T.; Yin, D.D. Organics removal of combined wastewater through shallow soil infiltration treatment: A field and laboratory study. J. Hazard. Mater. 2007, 149, 657-665. [CrossRef] [PubMed]

46. Lenk, S.; Remmler, F.; Skark, C.; Zullei-Seibert, N. Removal capacity of riverbank filtration and conclusions for the operation of water abstraction plants. In Proceedings of the 5th International Symposium on Management of Aquifer Recharge, Berlin, Germany, 10-16 June 2005.

47. Sharma, L.; Greskowiak, J.; Ray, C.; Eckert, P.; Prommer, H. Elucidating temperature effects on seasonal variations of biogeochemical turnover rates during riverbank filtration. J. Hydrol. 2012, 428, 104-115. [CrossRef]

48. Saunders, D.L.; Kalff, J. Denitrification rates in the sediments of Lake Memphremagog, Canada-USA. Water Res. 2001, 35, 1897-1904. [CrossRef]

49. Berg, M.; Trang, P.T.K.; Stengel, C.; Buschmann, J.; Viet, P.H.; Dan, N.V.; Giger, W.; Stüben, D. Hydrological and sedimentary controls leading to arsenic contamination of groundwater in the Hanoi area, Vietnam: The impact of iron-arsenic ratios, peat, river bank deposits, and excessive groundwater abstraction. Chem. Geol. 2008, 249, 91-112. [CrossRef]

50. Jiao, J.J.; Wang, Y.; Cherry, J.A.; Wang, X.S.; Zhi, B.F.; Du, H.Y.; Wen, D.G. Abnormally High Ammonium of Natural Origin in a Coastal Aquifer-Aquitard System in the Pearl River Delta, China. Environ. Sci. Technol. 2010, 44, 7470-7475. [CrossRef] [PubMed]

51. Wang, Y.; Jiao, J.J.; Cherry, J.A.; Lee, C.M. Contribution of the aquitard to the regional groundwater hydrochemistry of the underlying confined aquifer in the Pearl River Delta, China. Sci. Total Environ. 2013, 461, 663-671. [CrossRef] [PubMed]

52. Li, L.; Lollar, B.S.; Li, H.; Wortmann, U.G.; Couloume, G.L. Ammonium stability and nitrogen isotope fractionations for $-\mathrm{NH}_{3}(\mathrm{aq})-\mathrm{NH}_{3}$ (gas) systems at $20-70{ }^{\circ} \mathrm{C}$ and $\mathrm{pH}$ of 2-13: Applications to habitability and nitrogen cycling in low-temperature hydrothermal systems. Geochim. Cosmochim. Acta 2012, 84, 280-296. [CrossRef]

53. Norrman, J.; Sparrenbom, C.J.; Berg, M.; Nhan, D.D.; Jacks, G.; Ringdahl, P.H.; Nhan, P.Q.; Rosqvist, H. Tracing sources of ammonium in reducing groundwater in a well field in Hanoi (Vietnam) by means of stable nitrogen isotope $(\delta 15 \mathrm{~N})$ values. Appl. Geochem. 2015, 61, 248-258. [CrossRef]

54. Possemiers, M.; Huysmans, M.; Batelaan, O. Influence of Aquifer Thermal Energy Storage on groundwater quality: A review illustrated by seven case studies from Belgium. J. Hydrol. 2014, 2, 20-34. [CrossRef] 
55. Krause, S.; Tecklenburg, C.; Munz, M.; Naden, E. Streambed nitrogen cycling beyond the hyporheic zone: Flow controls on horizontal patterns and depth distribution of nitrate and dissolved oxygen in the upwelling groundwater of a lowland river. J. Geophys. Res. 2013, 118, 54-67. [CrossRef]

56. Barnes, R.T.; Smith, R.L.; Aiken, G.R. Linkages between denitrification and dissolved organic matter quality, Boulder Creek watershed, Colorado. J. Geophys. Res. 2012, 117, 1-14. [CrossRef]

57. Bekele, E.; Toze, S.; Patterson, B.; Higginson, S. Managed aquifer recharge of treated wastewater: Water quality changes resulting from infiltration through the vadose zone. Water Res. 2011, 45, 5764-5772. [CrossRef] [PubMed]

58. Regnery, J.; Barringer, J.; Wing, A.D.; Hoppe-Jones, C.; Teerlink, J.; Drewes, J.E. Start-up performance of a full-scale riverbank filtration site regarding removal of DOC, nutrients, and trace organic chemicals. Chemosphere 2015, 127, 136-142. [CrossRef] [PubMed]

59. Wang, C.; Wang, P.F.; Hu, X. Removal of $\mathrm{COD}_{\mathrm{Cr}}$ and nitrogen in severely polluted river water by bank filtration. Environ. Technol. 2007, 28, 649-657. [CrossRef] [PubMed]

(C) 2018 by the authors. Licensee MDPI, Basel, Switzerland. This article is an open access article distributed under the terms and conditions of the Creative Commons Attribution (CC BY) license (http://creativecommons.org/licenses/by/4.0/). 